\title{
Greedy southern pale chanting goshawk Melierax canorus
}

Author(s):

Franke-Bryson U
Journal editor:

Pete Laver

Manuscript editor:

Pete Laver

Received: July 26, 2018; Accepted: April 20, 2019; Published: April 20, 2019

\section{Citation: Franke-Bryson U. 2019. Greedy southern pale chanting goshawk Melierax canorus. Biodiversity Observations 10.8:1-7}

Journal: https://journals.uct.ac.za/index.php/BO/

Manuscript: https://journals.uct.ac.za/index.php/BO/article/view/628

PDF: https://journals.uct.ac.za/index.php/BO/article/view/628/595

HTML: http://thebdi.org/blog/2019/04/20/greedy-southern-pale-chanting-goshawk
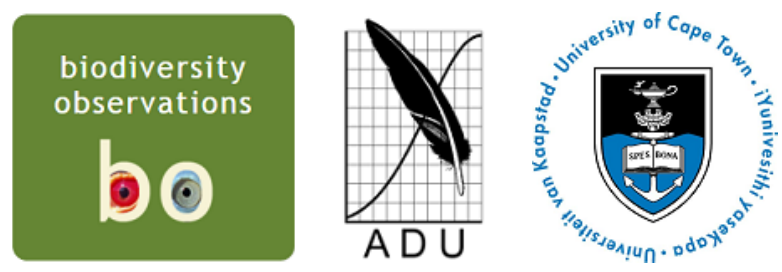

Biodiversity Observations is an open access electronic journal published by the Animal Demography

Unit at the University of Cape Town, available at https://journals.uct.ac.za/index.php/BO/

The scope of Biodiversity Observations includes papers describing observations about biodiversity in general, including animals, plants, algae and fungi. This includes observations of behaviour, breeding and flowering patterns, distributions and range extensions, foraging, food, movement, measurements, habitat and colouration/plumage variations. Biotic interactions such as pollination, fruit dispersal, herbivory and predation fall within the scope, as well as the use of indigenous and exotic species by humans. Observations of naturalised plants and animals will also be considered. Biodiversity Observations will also publish a variety of other interesting or relevant biodiversity material: reports of projects and conferences, annotated checklists for a site or region, specialist bibliographies, book reviews and any other appropriate material. Further details and guidelines to authors are on the journal website (https://journals.uct.ac.za/index.php/BO/). 


\title{
Greedy southern pale chanting goshawk Melierax canorus
}

\author{
Ursula Franke-Bryson Tal 34, Munich, Germany
}

\section{Summary}

Southern pale chanting goshawks (Melierax canorus) never miss an opportunity for feeding on any creature living or dead. Here three birds are recorded with the beak or crop still full, and hunting techniques and diet are described.

\section{Introduction}

Southern pale chanting goshawk hunting skills encompass a great variety of techniques. They hunt alone or in groups. They mainly hunt smaller prey, but are capable of killing animals heavier than themselves. The local available biodiversity determines the composition of the diet, which is generally highly diverse. Among recorded prey items are mammals (mainly rodents), birds (a variety of species ranging from larks, swallows, weavers to the size of francolin, korhaan, sandgrouse, owls and guineafowl) (Malan and Crowe 1996). Predation records have included a stunned rock kestrel or sometimes chickens (Steyn 1982). Southern pale chanting goshawks have also been recorded predating reptiles, amphibians, and invertebrates (sunspiders, harvester termites, grasshoppers, beetles and other insects). Southern pale chanting goshawks also feed on carrion of any kind, from hares to owls (Stein 1982; Biggs et al. 1984; Malan and Crowe 1996; Allan 2005). In one incident they might have detected a carcass of an Egyptian goose (Alopochen aegyptiaca) by observing Cape crows (Corvus capensis) gathering nearby (Ryan et al. 2012).

Steyn (1982) reports lizards as the most common prey in Kenya, while a study in the Western Cape Province, South Africa, found that more than $90 \%$ of the diet consisted of three species of rodents: Karoo bush rat (Myotomys (Otomys) unisulcatus), Brants' whistling rat (Parotomys brantsii) and four-striped grass mouse (Rhabdomys pumilio) (Malan and Crowe 1996). Malan (2017) found leopard tortoise (Stigmochelys pardalis) hatchlings being preyed upon, but only in their first two weeks while their carapaces, the outer shells, were still soft. In the arid savannah near Usakos, Namibia, $\left(22^{\circ} 24^{\prime} \mathrm{S} ; 5^{\circ} 25^{\prime} \mathrm{E}\right)$, I once saw two juvenile southern pale chanting goshawks, in the presence of one adult, dropping down clumsily on three young bat-eared foxes (Otocyon megalotis) who made it in time to their distant underground den, while the adult fox was defensively snapping into the air towards the attacking birds. It is unclear whether this behaviour was curiosity, hunting instinct, honing the hunting skills of the juveniles, or a serious attempt at predation in the harsh environment.

Biodiversity Observations is an open access electronic journal published by the Animal Demography Unit at the University of Cape Town, available at https://journals.uct.ac.za/index.php/BO/. A permanent link for an online version of this manuscript can be found at https://journals.uct.ac.za/index.php/BO/article/view/628, which includes the PDF: https:/ /journals.uct.ac.za/index.php/BO/article/view/628/595. An HTML version can be found at http:/ / thebdi.org/blog/2019/04/20/greedy-southern-pale-chanting-goshawk.

Journal editor: Pete Laver; Manuscript editor: Pete Laver; Corresponding author: praxis@ursula-franke.de Received: July 26, 2018; Accepted: April 20, 2019; Published: April 20, 2019

Recommended citation: Franke-Bryson U. 2019. Greedy southern pale chanting goshawk Melierax canorus. Biodiversity Observations 10.8:1-7

Manuscript subject: Avian diet 
Southern pale chanting goshawks perch high up to swoop down on prey and may pursue their prey swiftly on foot, if needed. They run so "blisteringly fast with these long legs" that "they easily can catch a sunspider" (Malan 2017). In strong wind, hunting may be restricted to the ground (pers. obs.). Although most prey are caught on the ground, birds can also be predated in flight, as Steyn (1982) observed during predation on a crowned plover (Vanellus coronatus) and a harlequin quail (Coturnix delegorguei).

Southern pale chanting goshawks are also known to take advantage of the hunting skills of other animals, and follow mammals (mainly honey badger, Melivora capensis, and slender mongoose, Galerella sanguinea), other birds, and possibly rock monitors (Varanus albigularis), who all could flush prey by their presence, by digging and exploring holes. Pale chanting goshawks have been sighted hoping for secondary prey from a Cape cobra (Naja nivea) (Siebert and Siebert 2003; Vanderwalt 2016), and kleptoparasitising a booted eagle (Hieraaetus pennatus) (in Malan 1998, p. 199) and a pipit from a kestrel (Steyn 1982).

\section{Observation}

We have caught two different southern pale chanting goshawk individuals, which had swallowed lizards directly before our observations - the tail of a lizard was still sticking out of the throat when each came swooping down to its next prey in the form of a mouse in a trap (Figures 1 and 2). Bird ringers might have experienced that a southern pale chanting goshawk will repeatedly try to take the bait whenever an attempt (or more) of catching the bird with a balchatri trap has failed. A bal-chatri is a cage containing a live rodent used to attract the attention of the raptor, and with nooses or fishline on top of the cage to entangle the raptor's feet when landing and trying to catch the bait (de Beer 2001).

A further adult female was trapped and ringed coming straight from a fresh helmeted guineafowl (Numida meleagris) kill. All flesh had been consumed. The southern pale chanting goshawk came to the bal-chatri already with a huge crop (Figures 3 and 4). As the site was near a gravel road, it remains unclear whether the southern pale chanting goshawk had killed the guineafowl or whether it had been hit by a car.

\section{Acknowledgements}

I am grateful to Susan Mvungi from the Niven Library, Percy FitzPatrick Institute of African Ornithology, University of Cape Town, for supporting me with access to literature, and to Dane Paijmans for revising the text.

\section{References}

Allan DG 2005. Southern Pale Chanting Goshawk. In: Hockey PAR, Dean WRJ, Ryan PG (eds). Roberts Birds of Southern Africa. 7th Ed. The Trustees of the John Voelcker Bird Book Fund, Cape Town. pp 509-511.

de Beer SJ, Lockwood GM, Raijmakers JHFA, Raijmakers JMH, Scott WA, Oschadleus HD, Underhill LG 2001. SAFRING bird ringing manual. 2nd Ed. Animal Demography Unit, Cape Town.

Biggs HC, Biggs R, Freyer E 1984. Observations on the Chanting Goshawk Melierax canorus during a period of poor rainfall. Proceedings of the Second Symposium on African Predatory Birds 61-70. Natal Bird Club, Durban. 


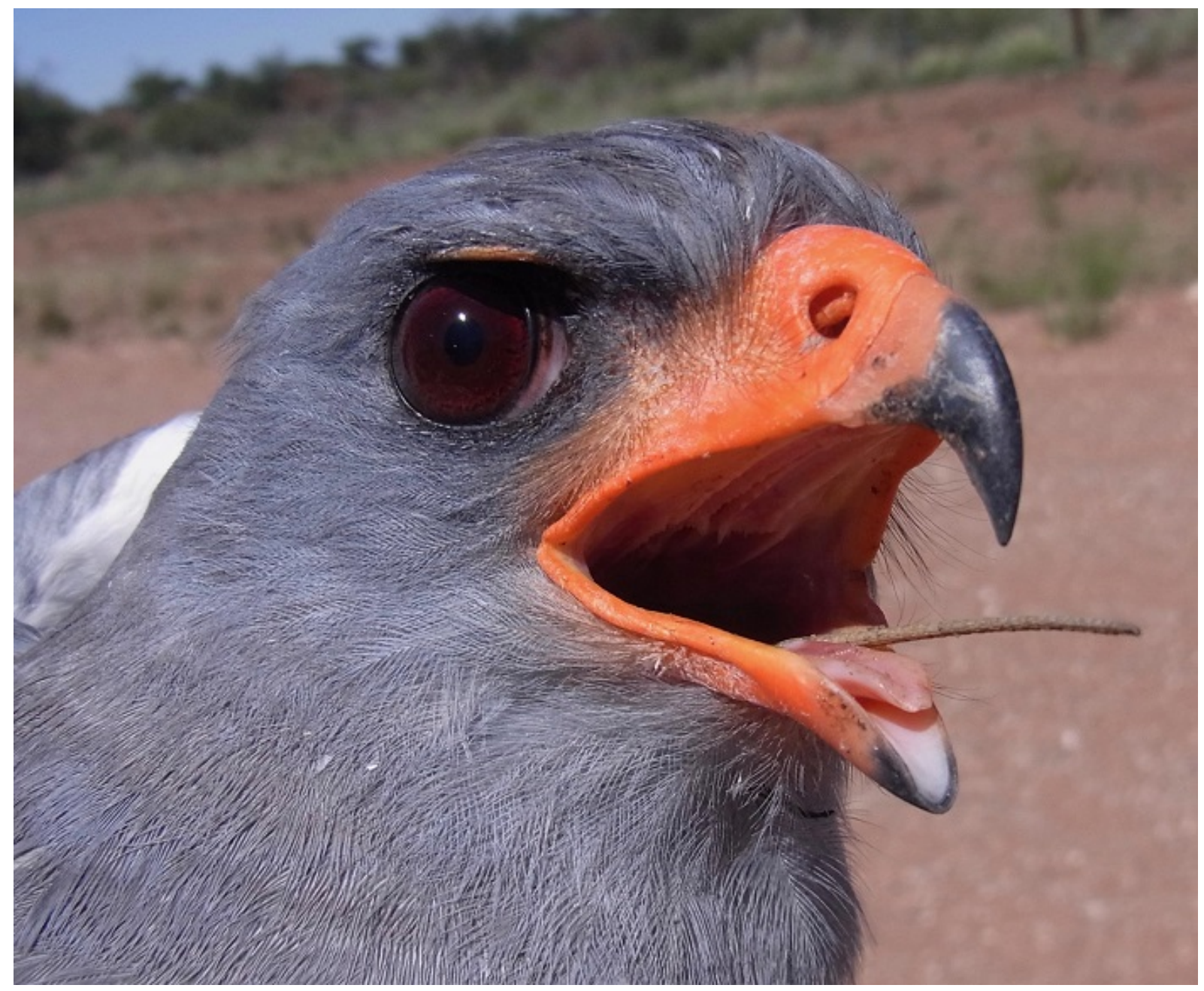

Figure 1: Adult female, the tail of a lizard still sticking out of her beak. Safring ring number 723669 , ringed north of Witvlei, Namibia $\left(22^{\circ} 24^{\prime} \mathrm{S} ; 18^{\circ} 30^{\prime} \mathrm{E}\right)$. 


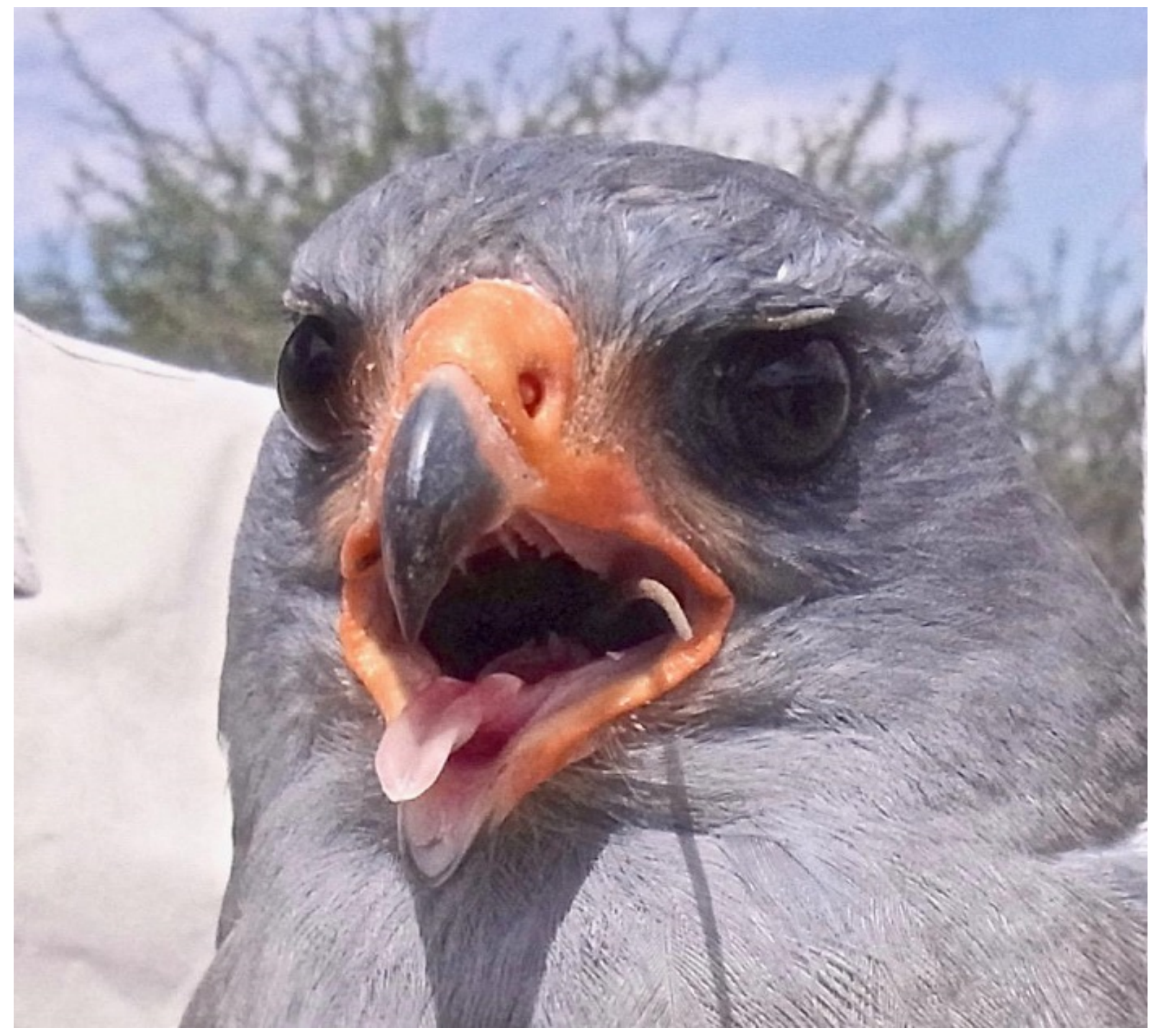

Figure 2: Adult male, the tail of a lizard still sticking out of his beak. Safring ring number K34924, ringed near Omitara, Namibia (22 $\left.2^{\circ} 1^{\prime} \mathrm{S} ; 17^{\circ} 40^{\prime} \mathrm{E}\right)$. 


Biodiversity Observations 10.8:1-7 $\quad$ bo $\quad$ Greedy southern pale chanting goshawk

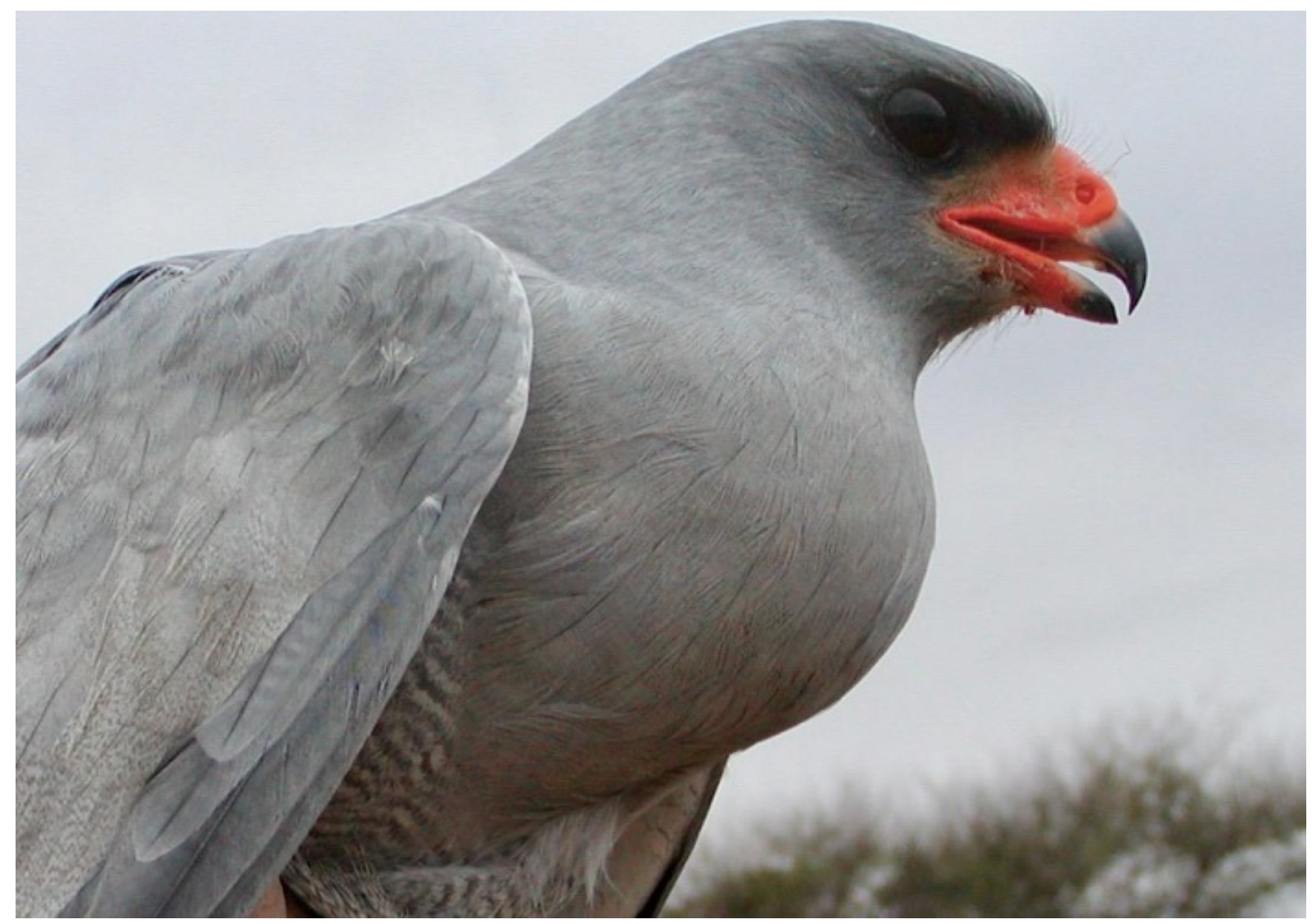

Figure 3: A bulging crop which contains a helmeted guineafowl, Limpopo Province, South Africa. (Photo credit: Lyn Williams) 


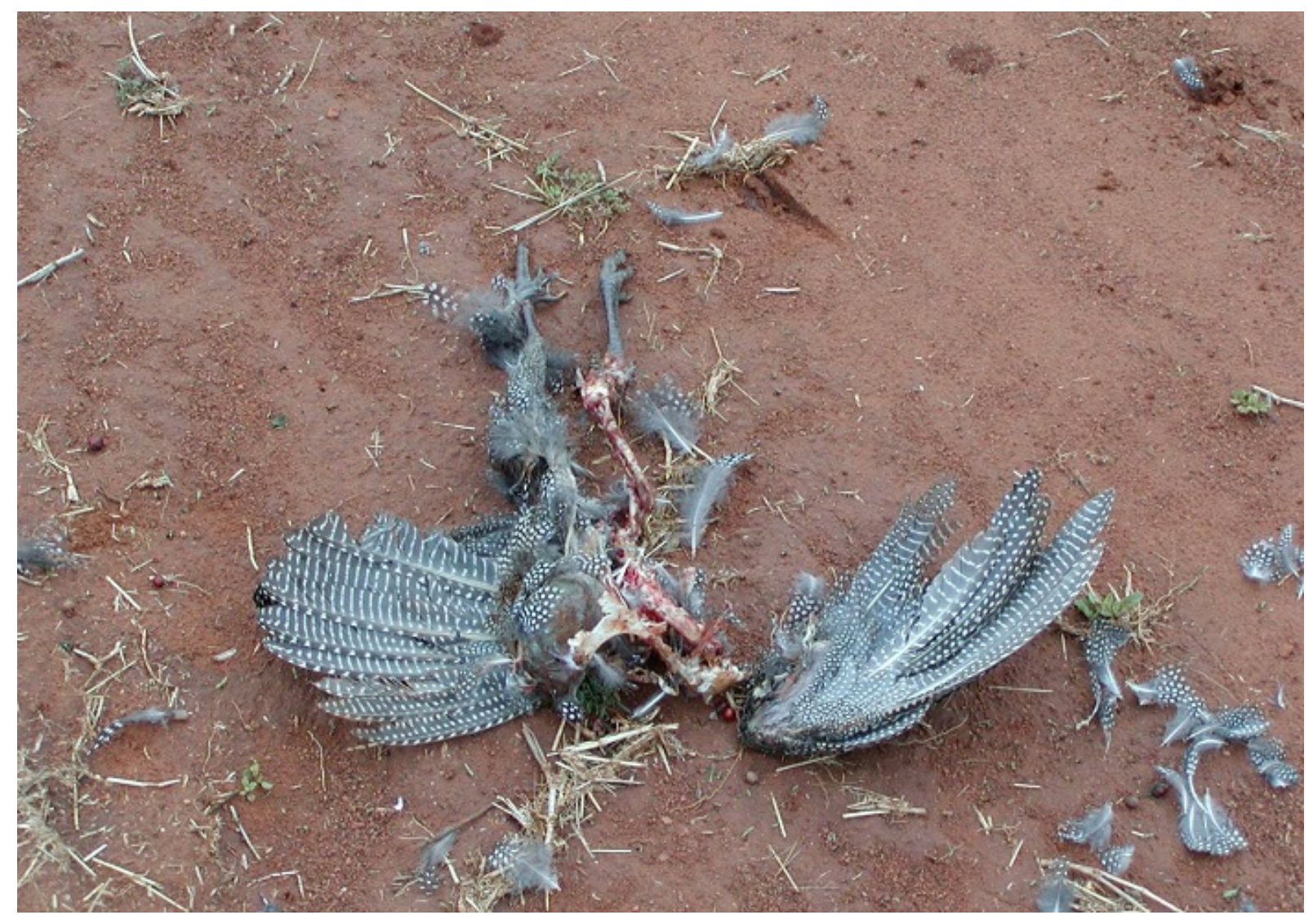

Figure 4: The remains of the helmeted guineafowl. (Photo credit: Lyn Williams) 
Ferguson-Lees J, Christie DA 2001. Raptors of the world. Christopher Helm, London. pp 512-513.

Kemp AC, Kirwan GM 2017. Pale Chanting Goshawk Melierax canorus. In: del Hoyo J, Elliott A, Sargatal J, Christie DA, de Juana E (eds). Handbook of the Birds of the World Alive. Lynx Edicions, Barcelona. Available from http://www.hbw.com/node/53039 (Accessed on on 29.10.2017).

Malan G 1998. Solitary and social hunting in Pale Chanting Goshawk Melierax canorus families: why use both strategies? Journal of Raptor Research 32:195-201.

Malan G 2017. The singing Goshawk. Available from http:/ / www.wildcard.co.za/the-singinggoshawk/ (Accessed on on 20.7.2018).

Malan G, Crowe TM 1996. The diet and conservation of monogamous and polyandrous Pale Chanting Goshawks in the Little Karoo, South Africa. South African Journal of Wildlife Research 26:1-10.

Ryan PG, Shaw JM, van der Merwe R, van der Merwe E 2012. Carrion attraction: goshawks and other birds captured on camera traps. Ornithological Observations 3:102-106. Available from http:/ / bo.adu.org.za/content.php?id=49 (Accessed on on 29.10.2017).

Siebert S, Siebert P 2003. Pale Chanting Goshawk following Cape Cobra. Promerops 254:19.

Steyn P 1982. Birds of prey of Southern Africa. Their identification and life histories. David Philip, Cape Town. pp 183-186.

Vanderwalt B 2016. Co-operative feeding. Biodiversity Observations 7.71:1. Available from http:/ / bo.adu.org.za/content.php?id=264 (Accessed on 29.10.2017). 